\title{
Effectiveness of an Instructional Program on Basic Education College Students Knowledge concerning risk of blood hyper viscosity among young adulthood at University of Sumer in Thi- Qar governorate
}

\author{
Hassan Jabber Hashem ${ }^{1}$, Dr. Huda Baker Hassan ${ }^{2}$ \\ ${ }^{I}$ (Adults nursing, College of Nursing, University of Baghdad, Iraq) \\ 2 (PhD in Adults Nursing, College of Nursing, University of Baghdad, Iraq)
}

\begin{abstract}
Background: A quasi-experimental study was carried out at the College of Basic Education, University of Sumer in Thi-Qar governorate starting from September $27^{\text {th }} 2016$ to May $1^{\text {st }} 2017$.

Objective: The study aims to evaluate the effectiveness of the instructional program on student knowledge toward the risk of blood hyperviscosity among adulthood and to find out the relationship between student demographic characteristics and effectiveness of instructional program.

Methodology: A purposive (Non-probability) sample of (60) students was divided into two groups, case group consisted of 30 students who exposed to instructional program and control group consisted of 30 students were not exposed to the program on students who studies in the College of Basic Education, University of Sumer in Thi-Qar governorate. The questionnaire consists of two parts, the first part is related to sociodemographic data and health information of students which as 16 items and the second part is related to students' knowledge which consists of 7 domains dealing 102 items. A descriptive statistical analysis was applied (frequency, and percentage) and inferential analysis (ANOVA) were used to analysis the data.

Results: The findings of the present study indicates that the students' knowledge for case group which exposed to instructional program were improved at post test for all domains through their correct answers which as $26.2 \%$ of students responses was correct at pre-test and changed to $71.2 \%$ at post-test, there were significant relationship between the effectiveness of instructional program and students age, and there housing of students Conclusion: The study concluded that there were effectiveness of instructional program on student's knowledge toward the risk of blood hyper viscosity in College of Basic Education-University of Sumer in Thi-Qar governorate

Recommendations: The study recommends to Increase health awareness among young people through the implementation of courses and lectures for youth in order to control the causes of chronic disease and their risks, and work on the completion of educational programs about the danger of smoking to reduce the serious complications and a law firm to reduce the phenomenon of water pipe in cafes and clubs.
\end{abstract}

Keywords: Instructional Program, Blood hyper viscosity, Knowledge.

\section{Introduction}

Blood hyper viscosity refers to any state in which there is increased viscosity of the blood. Increased serum viscosity usually results from increased circulating serum immunoglobulins eg, macroglobulinaemia, multiple myeloma and can also result from increased cellular blood components eg, red or white blood cells in hyperproliferative states eg, leukaemias, polycythaemia and thrombocythaemia(1).

Whole blood comprises red and white blood cells and platelets which are suspended in plasma, a tissue fluid that consists of water, important salts, and proteins, each of which has specific properties. The thickness or viscosity of the blood is determined by the number and size of the blood cells, as well as by the protein constituents of the plasma. An increase in the viscosity of the blood is an important complication encountered in Waldenström's macroglobulinemia. Increased viscosity results from the physical presence of the IgM paraprotein in the bloodstream (2).

The precise incidence of hyperviscosity is not known, as it may occur in a large number of conditions. Hyperviscosity may occur at any age but the etiology of that seen in infants is different from that seen in adults. Hyperviscosity occurs as a result of a raised haematocrit or due to increased levels of circulating plasma components. Many conditions may produce this state, including: Waldenström's macroglobulinaemia (most common cause), Multiple myeloma, Polycythaemia rubra vera, Leukemia (both acute and chronic), Connective tissue disorders eg, rheumatoid arthritis, Retinoic acid therapy, Cryoglobulinaemia, Chronic hypoxia and Paraneoplastic syndromes (hyperviscosity results from the large amounts of circulating immunoglobulins, cryoglobulins, paraproteins or antibodies, or due to an excessive increase in blood cells (3). 
Viscosity is a property of liquid and is described as the resistance that a liquid exhibits to the flow of one layer over another. As serum proteins or cellular components increase, the blood becomes more viscous. Vascular stasis and resultant hypo perfusion then lead to the clinical symptoms of hyperviscosity . The normal relative serum viscosity ranges from 1.4-1.8 units (reported as Centipoises). Symptoms usually are not seen at viscosities of less than 4 units, and hypervicosity typically requires a viscosity greater than 5 units. Hypervicosity is associated most commonly with plasma cell dyscrasias (4).

The paraproteinemias and is due to the large size of the excess immunoglobulin $\mathrm{M}(\mathrm{IgM})$ paraproteins in these disorders. Waldenström macroglobulinemia is the most common cause and accounts for about $85 \%$ of cases of Hypervicosity. Less frequently, Hypervicosity can occur in multiple myeloma (especially with myeloma proteins of the IgA and IgG3 types) and connective tissue diseases. Chen and colleagues describe seven cases of polyclonal Hypervicosity caused by IgG4-related disease (5).

Thus, prompt recognition and expeditious treatment are imperative in preventing deterioration little epidemiologic information is available on hyperviscosity. One study found that $61 \%$ of blood dyscrasias occur in males. Most blood dyscrasias are not diagnosed until the seventh decade of life. Mortality is related to the underlying cause of the hyperviscosity(6).

The symptoms of a raised blood viscosity result from sluggish flow of blood through the blood vessels. When occurring in the cerebral system, this may result in fuzzy-headedness, headaches, blurred vision, double vision, poor concentration and thinking, and, in severe cases, even reduced levels of consciousness. The risk of stroke is also higher under these circumstances. Sluggish blood flow through the lungs may result in breathing difficulty. Impaired flow through the coronary circulation may lead to chest pains due to angina in a patient prone to this problem. In patients with underlying heart problems, the development of 'heart failure' may occur, poor leg circulation characterized by pain when walking that improves with rest All the above symptoms may be aggravated by the presence of anemia( 7).

As plasmapheresis removes the circulating paraproteins, the serum viscosity decreases and symptoms improve. This procedure remains effective short-term treatment for hyperviscosity in the paraproteinemias because of the demonstrated correlation of paraprotein levels and serum viscosity and the $80 \%$ intravascular location of paraproteins, especially immunoglobulins (eg, in Waldenstr öm macroglobulinemia). As such, a relatively small reduction in the paraprotein concentration has a significant effect on lowering serum viscosity (8).

In an emergency situation in which a patient is experiencing life-threatening effects of a raised blood viscosity and access to plasmapheresis is not immediately available. An improvement in blood flow may be achieved by a therapeutic venesection (removal of $250-300 \mathrm{mls}$ of blood from a vein), with simultaneous replacement of normal saline or packed red cells, depending on the degree of anemia that is present. This maneuver can be carried out pending plasmapheresis to improve flow of blood to vital organs (9).

\section{Methodology}

Design of the Study: A quasi-experimental design study is carried out through the application of pre-test and post-test approach for the study and control groups, from the period of September, 27th 2016 to May, 1st 2017. Setting of the Study: The present study is carried out in College of Basic Education-University of Sumer in Thi-Qar governorate..

Sample of the Study: A purposive (Non probability) sample of (60) students are selected. The sample is divided into two groups; (30) students (case group) are exposed to the instructional program and (30) students are not exposed to the program, considered as a control group. The selection of case group and control group was randomly systematic selection.

Instrument To evaluate the effectiveness of instructional program, the researcher has constructed the instrument for the purpose of data collection, it consists of two parts:

Part I: The demographic data includes students characteristic, which as age, gender, marital status, family income level, and housing, and include the medical information as suffering diseases, diet, smoking and drinking

Part II: Checklist consists of seven domains; dealing ;students' knowledge about blood components and definition of blood hypervicosity (15) items;students' knowledge about the pathological of blood hypervicosity (8) items; students' knowledge about the causes of increased blood viscosity (15) items; students' knowledge about the symptoms and the risk of about (16) items; students knowledge about how to diagnose of blood hypervicosity (7) items; students' knowledge about the complications and treatment of blood hypervicosity (13) items; students knowledge about the prevention of blood hyperviscosity (28) items

Statistical Analysis: The data have been analyzed through the application of: descriptive frequency, percentages; Arithmetic Mean and Std. Dev. (S.D.); and the inferential analysis that include: (ANOVA) were used, and the researcher used the SPSS version 20 to analysis of data. 


\section{Results}

Table (1): Distribution of the Study Sample by Demographic Data for (Case and Control Group)

\begin{tabular}{|c|c|c|c|c|c|}
\hline \multirow[t]{2}{*}{ Variables } & \multirow[t]{2}{*}{ Classification } & \multicolumn{2}{|c|}{ Case Group(No=30) } & \multicolumn{2}{|c|}{ Control Group $(\mathrm{No}=30)$} \\
\hline & & Freq. & $\%$ & Freq. & $\%$ \\
\hline \multirow[t]{5}{*}{ Age } & $20-21$ & 4 & 13.3 & 3 & 10.0 \\
\hline & $22-23$ & 17 & 56.7 & 18 & 60.0 \\
\hline & $24-25$ & 7 & 23.3 & 8 & 26.7 \\
\hline & $26-27$ & 2 & 6.7 & 1 & 3.3 \\
\hline & $\overline{\boldsymbol{x}} \mp \boldsymbol{S} . \boldsymbol{D}$ & \multicolumn{2}{|c|}{${ }_{22.97} \bar{F}_{1.564}$} & \multicolumn{2}{|c|}{${ }_{22.90} \bar{F}_{1.125}$} \\
\hline \multirow[t]{2}{*}{ Gender } & Male & 14 & 46.7 & 10 & 33.3 \\
\hline & Female & 16 & 53.3 & 20 & 66.7 \\
\hline \multirow[t]{2}{*}{ Marital status } & Single & 24 & 80.0 & 19 & 63.3 \\
\hline & Married & 6 & 20.0 & 11 & 36.7 \\
\hline \multirow{3}{*}{ Residency } & Urban & 7 & 23.3 & 10 & 33.3 \\
\hline & Suburban & 17 & 56.7 & 14 & 46.7 \\
\hline & Rural & 6 & 20.0 & 6 & 20.0 \\
\hline \multirow[t]{3}{*}{ Current Housing } & Internal department & 9 & 30.0 & 7 & 23.3 \\
\hline & Independent house & 1 & 3.3 & 0 & 0.0 \\
\hline & With family & 20 & 66.7 & 23 & 76.7 \\
\hline \multirow{3}{*}{$\begin{array}{l}\text { Monthly Income of } \\
\text { Family }\end{array}$} & Enough & 14 & 46.7 & 16 & 53.3 \\
\hline & Barely Enough & 14 & 46.7 & 11 & 36.7 \\
\hline & Not Enough & 2 & 6.6 & 3 & 10.0 \\
\hline
\end{tabular}

Freq.=Frequencies, $\%=$ Percentages, $n=$ Size of Sample, $\geq=$ more Than or Equal.

The results of table 1 revealed that $56.7 \%$ of students in the case group and $60 \%$ of students in the control group at age group(22-23 years), 53.3\% of students in the case group were females and $66.7 \%$ of students in the a control group were females, $80 \%$ of students in the case group were single and $63.3 \%$ of students in the a control group were single, $56.7 \%$ of students in the case group and $46.7 \%$ of students in the a control group lived at Suburban area, $66.7 \%$ of students in the case group and $76.7 \%$ of students in the a control group living with family, $46.7 \%$ of students in the a case group and $53.3 \%$ of students in the control group was enough income.

Table 2: Medical Information and Personal Habits of the Study Sample (Case and Control Groups)

\begin{tabular}{|c|c|c|c|c|c|}
\hline \multirow[t]{2}{*}{ Variables } & \multirow[t]{2}{*}{ Classification } & \multicolumn{2}{|c|}{ Case Group $(\mathrm{No}=30)$} & \multicolumn{2}{|c|}{$\begin{array}{l}\text { Control } \\
\text { Group(No=30) }\end{array}$} \\
\hline & & Freq. & $\%$ & Freq. & $\%$ \\
\hline \multirow{3}{*}{$\begin{array}{l}\text { Do you suffer from increase the blood } \\
\text { viscosity }\end{array}$} & Yes & 0 & 0.0 & 2 & 6.7 \\
\hline & No & 19 & 63.3 & 17 & 56.6 \\
\hline & I don't Know & 11 & 36.7 & 11 & 36.7 \\
\hline \multirow[t]{2}{*}{ Hypertension } & Yes & 1 & 3.3 & 2 & 6.7 \\
\hline & No & 29 & 96.7 & 28 & 93.3 \\
\hline \multirow[t]{2}{*}{ Diabetes Mellitus } & Yes & 2 & 6.7 & 1 & 3.3 \\
\hline & No & 28 & 93.3 & 29 & 96.7 \\
\hline \multirow[t]{2}{*}{ High blood lipids } & Yes & 0 & 0.0 & 1 & 3.3 \\
\hline & No & 30 & 100.0 & 29 & 96.7 \\
\hline \multirow[t]{2}{*}{ Respiratory diseases } & Yes & 8 & 26.7 & 5 & 16.7 \\
\hline & No & 22 & 73.3 & 25 & 83.3 \\
\hline \multirow[t]{2}{*}{ Are you smokers? } & Yes & 4 & 13.3 & 8 & 26.7 \\
\hline & No & 26 & 86.7 & 22 & 73.3 \\
\hline \multirow[t]{5}{*}{ how many years of smoking } & None & 26 & 86.7 & 22 & 73.3 \\
\hline & $2-3$ & 0 & 0.0 & 2 & 6.7 \\
\hline & $4-5$ & 1 & 3.3 & 2 & 6.7 \\
\hline & $6-7$ & 2 & 6.7 & 1 & 3.3 \\
\hline & $\geq 8$ & 1 & 3.3 & 3 & 10.0 \\
\hline \multirow[t]{5}{*}{ The number of cigarettes per day } & None & 26 & 86.7 & 22 & 73.3 \\
\hline & 10 & 1 & 3.3 & 1 & 3.3 \\
\hline & 20 & 2 & 6.7 & 3 & 10.0 \\
\hline & 30 & 0 & 0.0 & 2 & 6.7 \\
\hline & 40 & 1 & 3.3 & 2 & 6.7 \\
\hline \multirow[t]{2}{*}{ Drinking water pipe } & Yes & 1 & 3.3 & 2 & 6.7 \\
\hline & No & 29 & 96.7 & 28 & 93.3 \\
\hline \multirow[t]{2}{*}{ Number the water pipe per day } & No & 29 & 96.7 & 28 & 93.3 \\
\hline & Yes & 1 & 3.3 & 2 & 6.7 \\
\hline \multirow[t]{2}{*}{ Do you drink alcohol? } & Yes & 0 & 0.0 & 1 & 3.3 \\
\hline & No & 30 & 100.0 & 29 & 96.7 \\
\hline
\end{tabular}


The results of table 2 revealed that $36.7 \%$ of the study sample case and control groups, they don't know if they suffer from increase the blood viscosity, $96.7 \%$ of students in a case group and $93.3 \%$ of students in a control group not have hypertension, $93.3 \%$ of students in the case group and $96.7 \%$ of students in the control group not have diabetes mellitus, $26.7 \%$ of students in the case group and $16.7 \%$ of students in the control group have respiratory problems, $13.3 \%$ of students in a case group and $26.7 \%$ of students in a control group was a smoker, $6.7 \%$ from the smoker in a case group and $10 \%$ from a smokers in the control group are smokes 20 cigarettes per day, $3.3 \%$ of students in the case group and $6.7 \%$ of students in the control group was smokes a water pipe.

Table (3): Distribution of the Study Sample by Dietary Habits for (Case and Control Group)

\begin{tabular}{|c|c|c|c|c|c|c|c|}
\hline \multirow[t]{2}{*}{ Variables } & \multirow{2}{*}{\multicolumn{3}{|c|}{ Classifications }} & \multicolumn{2}{|l|}{ Case } & \multicolumn{2}{|c|}{ Control } \\
\hline & & & & Freq. & $\%$ & Freq. & $\%$ \\
\hline \multirow[t]{2}{*}{ Taking Breakfast } & \multicolumn{3}{|l|}{ Yes } & 24 & 80.0 & 26 & 76.7 \\
\hline & \multicolumn{3}{|l|}{ No } & 6 & 20.0 & 4 & 13.3 \\
\hline \multirow[t]{5}{*}{ Meals Meat } & \multirow{5}{*}{\multicolumn{2}{|c|}{$\begin{array}{l}\text { How many times a } \\
\text { week you eat meat? }\end{array}$}} & None & 3 & 10.0 & 0 & 0.0 \\
\hline & & & $1-2$ & 9 & 30.0 & 12 & 40.0 \\
\hline & & & $3-4$ & 12 & 40.0 & 10 & 33.3 \\
\hline & & & $5-6$ & 2 & 6.7 & 5 & 16.7 \\
\hline & & & $\geq 7$ & 4 & 13.3 & 3 & 10.0 \\
\hline \multirow[t]{2}{*}{ Taking Heavy Liquids } & \multicolumn{3}{|l|}{ Yes } & 20 & 66.7 & 15 & 50.0 \\
\hline & \multicolumn{3}{|l|}{ No } & 10 & 33.3 & 15 & 50.0 \\
\hline \multirow[t]{8}{*}{ Drink Tea } & \multicolumn{3}{|l|}{ Yes } & 28 & 93.3 & 30 & 100.0 \\
\hline & \multicolumn{3}{|l|}{ No } & 2 & 6.7 & 0 & 0.0 \\
\hline & \multirow{6}{*}{$\begin{array}{l}\text { Times of } \\
\text { drink tea per } \\
\text { day }\end{array}$} & \multicolumn{2}{|c|}{ None } & 2 & 6.7 & 0 & 0.0 \\
\hline & & \multicolumn{2}{|l|}{1} & 5 & 16.6 & 7 & 23.3 \\
\hline & & \multicolumn{2}{|l|}{2} & 12 & 40.0 & 6 & 20.0 \\
\hline & & \multicolumn{2}{|l|}{3} & 8 & 26.7 & 7 & 23.3 \\
\hline & & \multicolumn{2}{|l|}{4} & 3 & 10.0 & 2 & 6.7 \\
\hline & & \multicolumn{2}{|c|}{$\geq 5$} & 0 & 0.0 & 8 & 26.7 \\
\hline \multirow{2}{*}{$\begin{array}{l}\text { Taking a lot of } \\
\text { Legumes }\end{array}$} & \multicolumn{3}{|l|}{ Yes } & 13 & 43.3 & 14 & 46.7 \\
\hline & \multicolumn{3}{|l|}{ No } & 17 & 56.7 & 16 & 53.3 \\
\hline
\end{tabular}

Freq. $=$ Frequencies, $\%=$ Percentages, $n=$ Size of Sample,

The results of table 3 revealed that $20 \%$ of students in a case group and $13.3 \%$ of students in a control group not taking breakfast, $40 \%$ of students in a case group they eat meat 3-4 times a week while $40 \%$ of students in the control group they eat meat 1-2 times a week, $33.3 \%$ of students in the case group and $50 \%$ of students in a control group not taking heavy liquids, $93.3 \%$ of students in a case group were drink tea $40 \%$ from them were drink tea 2 times per day and $100 \%$ of students in the control group drink tea $26.7 \%$ from them were drink tea $\geq 5$ times per day, $43.3 \%$ of students in the case group and $46.7 \%$ of students in the control group taking a lot of legumes.

Table (4): Students Responses for (Pre- Case and Pre Control) Regarding Instructional Program Concerning their Knowledge about Risk of Blood Hyperviscosity

\begin{tabular}{|c|c|c|c|c|c|c|}
\hline \multirow{2}{*}{$\begin{array}{l}\text { No. } \\
\text { Dom } \\
\text { ain }\end{array}$} & \multirow[t]{2}{*}{ Domains of Students' Knowledge } & \multirow{2}{*}{$\begin{array}{l}\text { No. } \\
\text { Items }\end{array}$} & \multicolumn{2}{|c|}{ Pre - Case } & \multicolumn{2}{|c|}{ Pre - Control } \\
\hline & & & I Know & $\begin{array}{l}\text { I don't } \\
\text { Know }\end{array}$ & I Know & $\begin{array}{l}\text { I don't } \\
\text { Know }\end{array}$ \\
\hline 1 & $\begin{array}{l}\text { Students' knowledge about blood components and definition of blood } \\
\text { hyperviscosity }\end{array}$ & 15 & $25.8 \%$ & $74.2 \%$ & $19.6 \%$ & $80.4 \%$ \\
\hline 2 & Students' knowledge about the pathological of blood hyperviscosity & 8 & $14.2 \%$ & $85.8 \%$ & $12.5 \%$ & $87.5 \%$ \\
\hline 3 & Students' knowledge about the causes of increased blood viscosity & 15 & $40.4 \%$ & $59.6 \%$ & $49.3 \%$ & $50.7 \%$ \\
\hline 4 & $\begin{array}{l}\text { Students' knowledge about the symptoms and the risk of increased blood } \\
\text { viscosity }\end{array}$ & 16 & $13.5 \%$ & $86.5 \%$ & $18.1 \%$ & $81.9 \%$ \\
\hline 5 & Students' knowledge about how to diagnoses of blood hyperviscosity & 7 & $41.0 \%$ & $59.0 \%$ & $45.7 \%$ & $54.3 \%$ \\
\hline 6 & $\begin{array}{l}\text { Students' knowledge about the complications and treatment of blood } \\
\text { hyperviscosity }\end{array}$ & 13 & $41.8 \%$ & $58.2 \%$ & $51.5 \%$ & $48.5 \%$ \\
\hline 7 & Students' knowledge about the prevention of blood hyperviscosity & 28 & $18.5 \%$ & $81.5 \%$ & $21.1 \%$ & $78.8 \%$ \\
\hline 8 & Total of Students' Knowledge for overall & 102 & $26.2 \%$ & $73.8 \%$ & $29.5 \%$ & $70.5 \%$ \\
\hline
\end{tabular}

Table 4 shows that the students' responses for pre case and pre control for total domains about their knowledge toward risk of blood hyperviscosity among young adulthood were nearest level of knowledge which of $73.8 \%$ don't know for case, and $70.5 \%$ don't know for control group. 
Table (5): Students' Responses for (Post- Case and Post Control) Regarding Instructional Program Concerning their Knowledge about Risk of Blood Hyperviscosity

\begin{tabular}{|c|c|c|c|c|c|c|}
\hline \multirow{2}{*}{$\begin{array}{l}\text { No. } \\
\text { Doma } \\
\text { in }\end{array}$} & \multirow[t]{2}{*}{ Domains of Students' Knowledge } & \multirow{2}{*}{$\begin{array}{l}\text { No. } \\
\text { Items }\end{array}$} & \multicolumn{2}{|c|}{ Post - Case } & \multicolumn{2}{|c|}{ Post - Control } \\
\hline & & & I Know & $\begin{array}{l}\text { I don't } \\
\text { Know }\end{array}$ & I Know & $\begin{array}{l}\text { I don't } \\
\text { Know }\end{array}$ \\
\hline 1 & $\begin{array}{l}\text { Students' knowledge about blood components and definition of blood } \\
\text { hyperviscosity }\end{array}$ & 15 & $71.3 \%$ & $28.7 \%$ & $25.3 \%$ & $74.7 \%$ \\
\hline 2 & Students' knowledge about the pathological of blood hyperviscosity & 8 & $67.5 \%$ & $32.5 \%$ & $19.6 \%$ & $80.4 \%$ \\
\hline 3 & Students' knowledge about the causes of increased blood viscosity & 15 & $66.4 \%$ & $33.6 \%$ & $52.0 \%$ & $48.0 \%$ \\
\hline 4 & $\begin{array}{l}\text { Students' knowledge about the symptoms and the risk of increased blood } \\
\text { viscosity }\end{array}$ & 16 & $75.4 \%$ & $24.6 \%$ & $22.5 \%$ & $77.5 \%$ \\
\hline 5 & Students' knowledge about how to diagnoses of blood hyperviscosity & 7 & $67.1 \%$ & $32.9 \%$ & $49.0 \%$ & $51.0 \%$ \\
\hline 6 & $\begin{array}{l}\text { Students' knowledge about the complications and treatment of blood } \\
\text { hyperviscosity }\end{array}$ & 13 & $70.3 \%$ & $29.7 \%$ & $53.8 \%$ & $46.2 \%$ \\
\hline 7 & Students' knowledge about the prevention of blood hyperviscosity & 28 & $74.0 \%$ & $26.0 \%$ & $25.7 \%$ & $74.3 \%$ \\
\hline 8 & Total of Students' Knowledge for overall & 102 & $71.2 \%$ & $28.8 \%$ & $33.8 \%$ & $66.2 \%$ \\
\hline
\end{tabular}

Table 5 shows that the student's responses for post case which exposed to instructional program and post control which not exposed to instructional program for total domains for their knowledge toward risk of blood hyperviscosity were improved at case group which as $71.2 \%$, comparison to knowledge of control group .

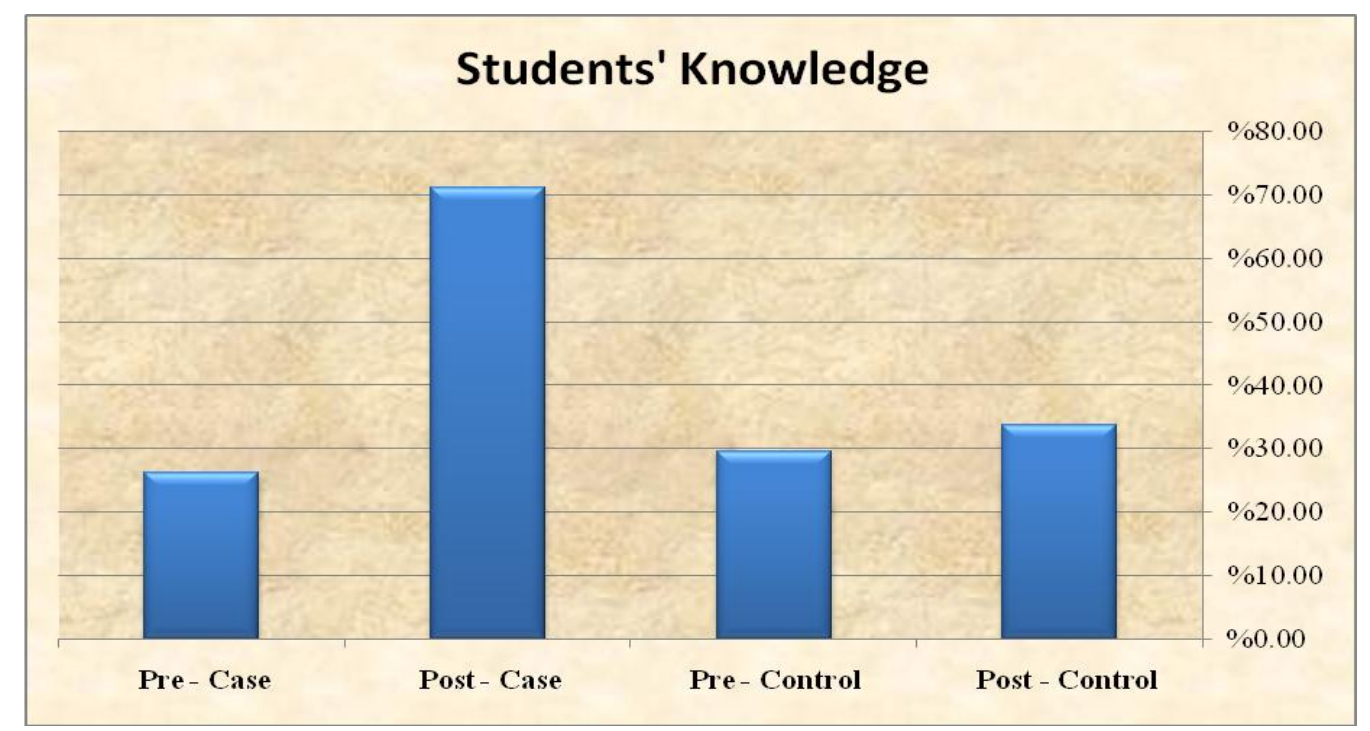

Figure 1: Students' Responses at Pre and Post test for case and control Groups

Figure 1 shows the effectiveness of instructional program was clear on case group between pre and post test comparative with control groups at pre and post

Table (6): Correlation between Students Knowledge and their Demographic data at Pre and Post Test for Case

\begin{tabular}{|l|l|c|c|}
\hline \multirow{2}{*}{ Variables } & & $\begin{array}{l}\text { Gre test for Total Domains } \\
\text { of Case Group }\end{array}$ & $\begin{array}{l}\text { Post test for Total } \\
\text { Domains of Case } \\
\text { Group }\end{array}$ \\
\hline \multirow{2}{*}{ Gender } & Correlation Coefficient & $-0.044-*$ & 0.027 \\
\cline { 2 - 4 } & Sig. (2-tailed) & 0.016 & 0.132 \\
\hline \multirow{2}{*}{ Age } & Correlation Coefficient & 0.004 & $-0.037-*$ \\
\cline { 2 - 4 } & Sig. (2-tailed) & 0.818 & 0.043 \\
\hline \multirow{2}{*}{ Marital Status } & Correlation Coefficient & $-0.012-$ & 0.009 \\
\cline { 2 - 4 } & Sig. (2-tailed) & 0.524 & -0.632 \\
\hline \multirow{2}{*}{ Residency } & Correlation Coefficient & 0.020 & 0.459 \\
\cline { 2 - 4 } & Sig. (2-tailed) & 0.268 & $0.039^{*}$ \\
\hline \multirow{2}{*}{$\begin{array}{l}\text { Housing of } \\
\text { students }\end{array}$} & Correlation Coefficient & 0.020 & 0.031 \\
\cline { 2 - 4 } & Sig. (2-tailed) & 0.264 & \\
\hline
\end{tabular}

\section{Significant: $P \geq \mathbf{0 . 0 5}$}


The results of table 6 revealed that there were significant relationship between the effectiveness of instructional program and students age, and there were significant relationship between housing of students and the effectiveness of instructional program for case group.

\section{Discussion}

Throughout the course of the data analysis of present study, the findings showed that the $56.7 \%$ of students in the case group and $60 \%$ of students in the control group at age group(22-23 years). This finding is supported by Hattab,(2014) The study conducted on 54 persons who attended to blood bank to blood donation at Baghdad city which indicated that the $50 \%$ of the study sample at age (18-32)years, $22.2 \%$ of them at age $23-27$ years old.The researcher believes that the blood hyperviscosity more common at age 23-32years old.

More than half $53.3 \%$ of students in the case group were females and $66.7 \%$ of students in the a control group were females. Shriraam, et al., (2015) shows in their study which conducted on 366 patients to assess their knowledge about chronic disease in India that the $76.5 \%$ of participants were females and $23.5 \%$ were males, and $\mathrm{Hu},(2015)$ presented in their study which conducted on 378 participants to improve the parents' knowledge about health problems in China were the most of the participants was female, the opinion of researcher that the female more interest than male to improve their knowledge, so they have big role in a family to avoid many health problems. Majority of the study sample $80 \%$ of students in the case group were single and $63.3 \%$ of students in the a control group were single. The researcher believes that the high percent of student in our study were not married so they are busy in a stuyding and they not have income to they bear responsibility of a family. More than half of students in the case group and $46.7 \%$ of students in the a control group lived at Suburban erea, $66.7 \%$ of students in the case group and $76.7 \%$ of students in the a control group living with family. Kumar, (2012) shows in their study which conducted on 251 persons in India to assess the knowledge and attitude of patients regarding diet, exercise that the $72.11 \%$ persons were lived in urban area.

The results of the present study shows that $46.7 \%$ of students in the a case group and $53.3 \%$ of students in the control group was enough income. Hattab,(2014) shows in their study the impact of hyperviscosity of blood on elevation of blood pressure among the adulthood at Baghdad city, that $44.4 \%$ of the study sample was sufficient income. The results of the present study revealed that the medical information of the case and control groups were $36.7 \%$ of the study sample in case and control groups they don't know if they suffer from increase the blood viscosity or not, and 6.7\% in control group have blood hyper viscosity . Malik, et al., (2014) supported the present findings through their assessment of 209 patients for knowledge, practice and drug adherence in a hospital in Samarkand, Uzbekistan that the $35.5 \%$ had inadequate knowledge about their diseases and inadequate knowledge about specific issues such as duration of treatment and symptoms of diseases.

The findings of present study revealed that $3.3 \%$ of students in a case group and $6.7 \%$ of students in a control group have hypertension, $6.7 \%$ of students in the case group and $3.3 \%$ of students in the control group have diabetes mellitus, $26.7 \%$ of students in the case group and $16.7 \%$ of students in the control group have respiratory problems, The researcher believes that the fast food and unhealthy foods that offered by fast-food restaurants are an essential source of unwanted calories and unhealthy fat especially for those looking for the best nutritional value, increased demand by young people on fast food due to speed and simplicity of buying this meals, and the stress of their a studying may led to these health problems.

The results of the present study shows that the $20 \%$ of students in a case group and $13.3 \%$ of students in a control group not taking breakfast, $40 \%$ of students in a case group they eat meat 3-4 times a week while $40 \%$ of students in the control group they eat meat 1-2 times a week Lubbad,(2011) determine in their study which conducted on 140 students $50 \%$ male and 50\% female at age 19 and up to 30 years, was chosen randomly from faculty of pharmacy at Al Azhar university in Gaza, that the $12 \%$ of male students and $49 \%$ of female students was consuming fast food and $37 \%$ of male students and $47 \%$ of female students eat red meat more than one time weekly. The results of present study revealed that $13.3 \%$ of students in a case group and $26.7 \%$ of students in a control group was a smoker, $6.7 \%$ from the smoker in a case group and $10 \%$ from a smokers in the control group are smokes 20 cigarettes per day, 3.3\% of students in the case group and $6.7 \%$ of students in the control group was smokes a water pipe.

Malik, et al., (2014) stated in their study which conducted on 209 patients to assess knowledge, practice and drug adherence among inpatients of a hospital in Samarkand, Uzbekistan that the 19.1\% of the Sample were smokers, and agree with Almarshad, et al., (2014) they revealed that the smoking lead to increase hematocrit level and blood viscosity. Low percent in present study sample were $3.3 \%$ in a case group and $6.7 \%$ of students in a control group was smokes a water pipe. Rice, (2012) states that several reviews on the negative effects of a water pipe on health outcomes. In addition, findings from specific studies associate water pipe with poor lung function, malignant lung disease, cancers of the mouth, coronary heart disease, and various other health problems. Cigarette smoking by adolescents is known to cause a number of health problems 
Majority of the study sample $93.3 \%$ of students in a case group were drink tea $40 \%$ from them were drink tea 2 times per day and $100 \%$ of students in the control group drink tea $26.7 \%$ from them were drink tea $\geq$ 5 times per day, Lubbad, (2011) presented in their study that the $37 \%$ of male students and $44 \%$ of female students were consuming tea. The researcher believes that the drink tea it has many benefits and few disadvantages, the tea important source of many antioxidants, pressure regulator and resistant to atherosclerosis. Disadvantages it inhibitor of iron absorption from the stomach, constipation, increased secretion of gastric acid .

The results of the presented study shows that the $43.3 \%$ of students in the case group and $46.7 \%$ of students in the control group taking a lot of legumes, this results agree with Lubbad, (2011) which indicated that the $33 \%$ of male students and $50 \%$ of female students eating a lot of legumes. The researcher believes that the eating a lot of legumes it's good dietary habit because the legumes (beans, corn, lentils, beans and peas) rich from the definition they contain a large amount of dietary protein and minerals, it e

qual to the meat in benefits but it's less disadvantages compared with meat The results of present study revelaed that the students knowledge for case group which exposed to instructional program were improved at post test for all domains of instructional program concerning hyperviscosity which as $26.2 \%$ of students was known about the items of program domains at pre test and changes to $71.2 \%$ of student known at post test.

These results supported by Wadi\&Hassan, (2015) concuded in their study which conducted in Iraqi national blood bank on 70 clients have Secondary Polycythemia that the clients knowledge for case group which exposed to instructional program were improved at post test than pre instructional program. The students responses at pre test for case and control group for total domains about their knowledge toward risk of blood hyperviscosity among young adulthood were nearest level of knowledge which of $73.8 \%$ don't know for many items of program for case, and $70.5 \%$ don't know for control group. This results agree with Wadi and Hassan,(2015) who presented in their study that the same level of knowledge toward all instructional program domains for case and control group at pre test.

The effectiveness of instructional program was a clear through the student's responses for post case which exposed to instructional program and post control which not exposed to instructional program for total domains for their knowledge toward risk of blood hyperviscosity were improved at case group which as $71.2 \%$ of student was known about the high number of instructional items comparison to knowledge of control group which as 33.8\% (table 5, and figure 1). The present findings supported by Hu, (2015) through their assessment which conducted on 378 participants to improve the parents' knowledge on health problems in East China, most of the participants were female, they responses toward health problems was poor befor exposed to program, and after exposed the program for the same participants their responses were correct answers increased. He concluded that a short education lecture made for patients had a good effect on their knowledge. Present study showes that there were significant relationship between the effectiveness of instructional program and students age, and housing of students for case group, This results agree with Kumar, (2012) in his study which conducted on 251 patients in India, he concluded there was significant association between Knowledge score and age, and patients housing. So these results supported by Huang, et al., (2015) they assessed knowledge improvement on 848 participants in a pharmacist-facilitated national community education program of adults related to medications, they determined in their study were significant relationship between the effectiveness of instructional program and their age. The age were significant determinants in the improvement of the pre-to-post program test score.

Present findings shows that there were not significant relationship between gender and effectiveness of instructional program at $P \geq 0.05$. This results disagree with Ahmed, et al., (2014) showes in their study which conducted on 600 participants from Karachi in Pakistan, they finded that the boys knowledge about blood donation better than girls. Present study shows that there were not significant relationship between the effectiveness of instructional program and students residency. This results agree with Kumar, (2012) in his study which conducted on 251 patients in India. He concluded there was significant association between Knowledge score and patients residence.

\section{Conclusion}

The study concluded that there was effectiveness of instructional program on student's knowledge toward risk of blood hyper viscosity in College of Basic Education-University of Sumer in Thi-Qar governorate

\section{Recommendations}

The study recommends to Increase health awareness among young people through the implementation of courses and lectures for youth in order to control the causes of chronic disease and their risks, and work on the completion of educational programs about the danger of smoking to reduce the serious complications and a law firm to reduce the phenomenon of water pipe in cafes and clubs. 


\section{References}

[1] Stone MJ, Bogen SA; Evidence-based focused review of management of hyperviscosity syndrome. Blood. 2012 Mar 8;119(10):2205-8. doi: 10.1182/blood-2011-04-347690. Epub 2011 Dec 6.

[2] Mehta J, Singhal S. Hyperviscosity syndrome in plasma cell dyscrasias. Semin Thromb Hemost 2003;29(5):467-71.

[3] Rampling MW; Hyperviscosity as a complication in a variety of disorders. Semin Thromb Hemost. 2003 Oct;29(5):459-65

[4] Kwaan HC. Hyperviscosity in plasma cell dyscrasias. Clin Hemorheol Microcirc. 2013. 55 (1):75-83.[Medline].

[5] Chen LY, Wong PC, Noda S, Collins DR, Sreenivasan GM, Coupland RC. Polyclonal hyperviscosity syndrome in IgG4-related disease and associated conditions. Clin Case Rep. 2015 Apr. 3 (4):217-26.[Medline].

[6] Adams BD, Baker R, Lopez JA, Spencer S. Myeloproliferative disorders and the hyperviscosity syndrome. Emerg Med Clin North Am. 2009 Aug. 27(3):459-76. [Medline]

[7] Mullen EC, Wang M. Recognizing hyperviscosity syndrome in patients with Waldenstrom macroglobulinemia. Clin J Oncol Nurs 2007;11(1):87-95.

[8] Ramos-Casals M, Stone JH, Cid MC, Bosch X. The cryoglobulinaemias. Lancet. 2012. 379(9813):348-360

[9] Ballestri M, Ferrari F, Magistroni R, Mariano M, Ceccherelli GB, Milanti G, et al. Plasma exchange in acute and chronic hyperviscosity syndrome: a rheological approach and guidelines study. Ann Ist Super Sanita 2007;43(2):171-5.

[10] Kumar, J.: Knowledge \& Attitude of Diabetic Patients Regarding Diabetic diet, Exercise and Foot care. International Journal of Nursing Education, Vol. 4 Issue 2, 2012, P: 141

[11] Hattab.: Impact of Hyperviscosity of Blood on Elevation of Blood Pressure among the Adulthood at Baghdad City. Kufa Journal For Nursing Sciences, Vol.5 No. 2, May through August 2015,P 1-8

[12] Shriraam, V.; Mahadevan, S.; Anitharani, M.; Jagadeesh, S.; Kurup, B.; Vidya, TA.; and Seshadri, KG.: Knowledge of hypoglycemia and its associated factors among type 2 diabetes mellitus patients in a Tertiary Care Hospital in South India. Indian J Endocrinol Metab.Vol. 19 (3), 2015, PP: 378-82.

[13] Malik, A.; Yoshida, Y.; Erkin, T.; Salim, D.; and Hamajima, N.: Hypertension-related knowledge, practice and drug adherence among inpatients of a hospital in Samarkand, Uzbekistan. Nagoya J Med Sci., Vol. 76 (3-4), 2014, PP: $255-63$.

[14] Wadi, A; Hassan, H: Effectiveness of an Instructional Program Concerning Secondary Polycythemia Knowledge on Clients Attending Iraqi National Blood Bank . kufa Journal for Nursing sciences Vol. 6 Issue 1, 2016, P: 111-112

[15] Lubbad,: Food Consumption Patterns and Dietary Habits Associated with Weight Status in Healthy Young Adult Students, AlAzhar University Thsis, 2011,P.P.31-60

[16] Almarshad, H.; and Hassan, F.: Alterations in Blood Coagulation and Viscosity Among Young Male Cigarette Smokers of Al-Jouf Region in Saudi Arabia. Sage Journals of Clinical and Applied Thrombosis/Hemostasis, 2014, PP: 1-4.

[17] Hu, Y.: Does an education seminar intervention improve the parents' knowledge on vaccination? Evidence from Yiwu, East China. International Journal of Environmental Research and Public Health, Vol. 12(4), 2015, PP: 3469,3473, 3474.

[18] Huang, YM.; Yang, YH.; Lin, SJ.; Chen, KC.; Kuo, CC.; and Wu, FL.: Medication knowledge to be improved in participants in community universities in Taiwan: Outcome of a nationwide community university program. Journal of the Formosan Medical Association = Taiwan yizhi, 2015, 114(12), PP:1267, 1270

[19] Ahmed, Z.; Zafar, M.; Khan, A.; Anjum, M.; and Siddique, M.: Knowledge, Attitude and Practices about Blood Donation among Undergraduate Medical Students in Karachi. J Infect Dis Ther, Vol. 2, (134), 2014, PP: 1-4.

[20] Rice, V.: Water Pipe Smoking Among the Young: The Rebirth of an Old Tradition, Nurs Clin North Am. Mar; 47(1), 2012, PP:141-148. 